\title{
BENEFIT OF ADDING SOFOSBUVIR TO INTERFERON AND RIBAVIRIN IN RETREATING CHRONIC HEPATITIS C PATIENTS NOT RESPONDING TO INTERFERON AND RIBAVIRIN
}

\author{
By
Mohamed Badry Bastawy, Medhat Hassan El-Sahhar **, Sayed Farouk Mohamed Ahmed*, Ahmed Hanafy Ahmed Soliman Khattab ** \\ Departments of Hepatogastroentrology and Infectious Diseases and* Biochemistry, \\ Faculty of Medicine- Al-Azhar University,** and Department of Hepatology and \\ Gastroenterology, Police Hospitals \\ *Corresponding Author: Ahmed Hanafy Ahmed Soliman Khattab, \\ E-Mail: ahmedkhattab78@yahoo.com, Mobile: (+20) 01006995477
}

\begin{abstract}
Background: Worldwide, more than one million people die each year from hepatitis C virus (HCV) related diseases, and over 300 million people are chronically infected with hepatitis B or C.

Objective: Studying the benefit of adding sofosbuvir to pegylated interferon and ribavirin in chronic hepatitis $\mathrm{C}$ patients not responding to interferon and ribavirin as regards virological response and liver fibrosis regression.

Patients and methods: A prospective study was conducted in cooperation with AL-Agouza Police Hospital. The enrolled patients were classified into two groups: Group (A): one hundred and fifty naïve patients with chronic HCV infection, and group (B): one hundred and fifty patients with chronic HCV infection who were non responders to prior treatment with pegylated interferon and ribavirin after at least 6 months of this treatment.

Enrolled patients were treated using interferon (IFN) based regemin that included Pegylated INF alpha + ribavirin (weight based; $1200 \mathrm{mg}$ if $\geq 75 \mathrm{Kg}$ or 1000 if $<75 \mathrm{Kg}$ of body weight) + sofosbuvir (400 mg/day for 12 weeks) according to National Committee for Control of Viral Hepatitis (NCCVH) hepatitis C treatment protocol update, May 2015.
\end{abstract}

PCR was done 4 weeks after starting treatment (RVR), at the end of treatment (ETR), 12, 24, 48 weeks after the end of treatment to assess virological response in both groups.

Fibroscan was done before treatment and 12-24 weeks after the end of treatment to assess liver fibrosis.

Results: Of the 300 patients included, SVR12 was achieved in 275 patients (92\%), SVR24 and SVR48 in 267 patients $(89 \%)$. There was a statistically significant difference between both studied groups as regards SVR12, SVR24 and SVR48 where group (A) showed better virological response than group (B).

Regression of fibrosis was achieved in both groups, and there was a statistically significant difference as regards pre-treatment and post-treatment fibroscan score in both groups.

Conclusion: Adding Sofosbuvir to Interferon and Ribavirin in retreating chronic hepatitis $\mathrm{C}$ patients not responding to Interferon and Ribavirin improved the response of treatment and caused regression of liver fibrosis.

Keywords: Sofosbuvir, Chronic Hepatitis C, SVR12, regression of liver fibrosis. 


\section{INTRODUCTION}

The highest prevalence of $\mathrm{HCV}$ infection is present in Egypt, with $92.5 \%$ of patients infected with genotype 4, 3.6\% patients with genotype 1, 3.2\% patients with multiple genotypes, and $<1 \%$ patients with other genotypes (Kouyoumjian et al., 2018).

Among patients with chronic $\mathrm{HCV}$, $35 \%-45 \%$ will develop some level of progressive liver disease; and without treatment, approximately 5\%-10\% will develop cirrhosis (10\%-20\% lifetime risk) and 1\%-3\% will develop hepatocellular carcinoma (HCC). An increase in incidence of $\mathrm{HCC}$ and other liver-related complications was expected, with estimated doubling of HCV-related mortalities between 2000 and 2020, reaching more than 35000 deaths per year in 2020 (Waked et al., 2014).

Treatment of HCV in Egypt has become one of the top national priorities since 2007. Egypt started a national treatment program intending to provide cure for Egyptian $\mathrm{HCV}$-infected patients. Mass HCV treatment program had started using Pegylated interferon and ribavirin between 2007 and 2014. Yet, with the development of highly-effective direct acting antivirals (DAAs) for $\mathrm{HCV}$, elimination of viral hepatitis has become a real possibility (Omran et al., 2018). In October 2014, the introduction of sofosbuvir markedly changed therapeutic outcomes. Ruane et al. treated 60 chronic hepatitis $\mathrm{C}$ patients of Egyptian ancestry with sofosbuvir and ribavirin for 12 wk or $24 \mathrm{wk}$. In their study, sustained virological response (SVR) rates ranged from $68 \%$ to
93\%, being more in patients who received 24 wk of therapy (Ruane et al., 2015).

The primary objective of this prospective study was to assess the benefit of adding sofosbuvir to interferon and ribavirin in chronic hepatitis C Egyptian patients non responders to interferon and ribavirin. A secondary objective was to assess post treatment fibrosis regression in enrolled patients at SVR12.

\section{PATIENTS AND METHODS}

A prospective study was conducted in cooperation with Al-Agouza Police Hospital. The enrolled cases were selected from Al-Agouza Police Hospital outpatient clinic. Our study was conducted on 300 patients with documented diagnosis of chronic HCV infection. The patients participating in the study have signed informed consent before the start of any study related procedure. Patients were classified into 2 groups:

- Group (A): One hundred and fifty naïve patients with chronic $\mathrm{HCV}$ infection.

- Group (B): One hundred and fifty patients with chronic $\mathrm{HCV}$ infection who were not responding to prior treatment with pegylated interferon and ribavirin after at least 6 months of this treatment.

\section{Both groups were subjected to the following:}

Careful full medical history taking, clinical examination and laboratory investigations (Routine liver function tests, complete blood picture, TSH and ANA levels, serum keratinize and random blood sugar, FBS, PPBS and HBA1c), 


\section{BENEFIT OF ADDING SOFOSBUVIR TO INTERFERON AND RIBAVIRIN... 413}

viral markers (HCV antibody by third generation enzyme linked immunosorbent assay, $\mathrm{HBs} \mathrm{Ag}$ by second generation enzyme linked immunosorbent assay andHCV RNA quantitative by PCR), tumour marker (Alfa fetoprotein), Fundus examination, ECG, abdominal ultrasound and fibroscan examination (Fibroscan ${ }^{\circledR}$, Echosens, Paris, France).

Fibro Scan was done to assess the degree of liver stiffness (LS), and was performed at $\mathrm{Al}$ agouza Police Hospital. A total of 10 measurements, expressed in $\mathrm{kPa}$, were obtained at each assessment and the median was determined.

LS score ranged from 2.50 to $75 \mathrm{kPa}$. Fibroscan values were used to estimate the METAVIR fibrosis stage as follows: F0F1: 2.5 to $6.9 \mathrm{kPa}$; F2: 7.0 to $9.4 \mathrm{kPa}$; F3: 9.5 to $12.4 \mathrm{kPa} ; \mathrm{F} 4: \geq 12.5 \mathrm{kPa}$. Cirrhosis was defined as an LS score of $12.5 \mathrm{kPa}$ or more. Data were analyzed for two time intervals: pre-treatment to the first FibroScan result obtained $\geq 12$ weeks after the end of treatment, which was used as the SVR12 score (Castera, 2012).

\section{Upper GI endoscopy (when indicated) was applied:}

\section{A. During treatment:}

1. CBC at 4, 8, 12 weeks.

2. Total Bilirubin at 4, 8, 12 weeks.

3. ALT and AST at 4, 8, 12 weeks.

4. Serum Creatinine at 4, 8, 12 weeks.

5. Serum albumin at $4,8,12$ weeks.

6. PCR after 4 and 12 weeks of treatment.

\section{B. Post treatment:}

1. PCR for HCV RNA at 12, 24, 48 weeks after the end of treatment.

2. Fibroscan at 12 to 24 after the end of treatment.

\section{Sample Size calculation and randomization:}

A sample of 300 patients with chronic liver disease according to the pre-designed inclusion criteria, were estimated using Epi-Info software to give the study a power of $80 \%$ at a significance level of 0.05 .

An informed consent was obtained from each of the participants or one of the responsible relatives before recruitment in the study.

\section{Inclusion Criteria:}

Patients with chronic hepatitis C infection that fulfilled the following criteria, were enrolled in the study and were treated using interferon (IFN) based regemin that included Pegylated INF alpha + ribavirin (weight based; $1200 \mathrm{mg}$ if $\geq 75 \mathrm{Kg}$ or 1000 if $<75 \mathrm{Kg}$ of body weight) + sofosbuvir $400 \mathrm{mg} /$ day for 12 weeks according to National Committee for Control of Viral Hepatitis (NCCVH) hepatitis C treatment protocol update, May 2015:

1. Age: 18-60 years old.

2. Detectable HCV RNA by polymerase chain reaction (CobasAmplicor HCV Monitor v2.0 [Roche Diagnostics, Branchburg, New Jersey]; lower limit of quantitation [50 $\mathrm{IU} / \mathrm{mL}]$.

3. Any body mass index (BMI).

4. All fibrosis stages.

5. Total bilirubin $\leq 1.2 \mathrm{mg} / \mathrm{dl}$. 
6. Serum albumin $\geq 3.5 \mathrm{mg} / \mathrm{dl}$.

7. $\mathrm{INR} \leq 1.2$

8. Hemoglobin $\geq 13 \mathrm{~g} / \mathrm{dl}$ for males and $\geq 12 \mathrm{~g} / \mathrm{dl}$ for females.

9. Total leucocytic count (TLC) $\geq$ $4000 / \mathrm{cmm}$

10. Platelets count $\geq 150000 / \mathrm{cmm}$.

11. ANA $\leq 2$ folds.

12. Absence of current auto-immune diseases including thyroid disease.

13. Absence of proliferative retinopathy.

14. Absence of unstable cardiac disease.

15. Non-organ transplant cases.

16. Absence of unstable neuropsychiatric disorder.

17.Absence of oesophageal and/or gastric varices.

\section{Exclusion Criteria:}

1. Patients refusing to be entitled in the study.

2. Child score B and C.

3. Ascites and hepatic encephalopathy whether now or history.

4. HCC, except 4 months after intervention aiming at cure with no history of activity by dynamic imaging (CT or MRI).

5. Serum creatinine $>2.5 \mathrm{mg} / \mathrm{dl}$ if creatinine was between 1.5 and 2.5 $\mathrm{mg} / \mathrm{dl}$, Glomerular Filtration Rate GFR was calculated and should exceed 30 $\mathrm{mL} / \mathrm{min}$. with favorable nephrological consultation.
6. Extrahepatic malignancy except after 2 years of disease-free interval.

7. Pregnancy or inability to use ineffective contraception.

8. Inadequately controlled diabetes mellitus.

9. Body mass index $(\mathrm{BMI}) \leq 30 \mathrm{~kg} / \mathrm{m} 2$.

\section{Statistical Analysis:}

Analysis of data was done by IBM computer using SPSS (statistical package for social science version 16 (Clinton Miller, 199)2 as follows:

- Description of quantitative variables as mean, SD, range, the median, and Inter quartile range IQR (1-3).

- Description of qualitative variables as number and percentage.

- Comparison between groups as regard quantitative variables by using t-test:

1. Student's t-test between two groups for a normally distributed quantitative variable.

2. Mann-Whitney test was used to compare two groups for not normally distributed quantitative variables.

Level of significance: For all above mentioned statistical tests done, the threshold of significance was fixed at $5 \%$ level (p-value).

The results were considered significant when the probability of error was less than $5 \%(\mathrm{p} \leq 0.05)$. 


\section{RESULTS}

Three hundreds of patients with HCV were divided into two groups:

- Group A; One hundred and fifty naïve patients with chronic HCV infection.

- Group B; One hundred and fifty patients with chronic $\mathrm{HCV}$ infection who were non responders to interferon and ribavirin at least 6 months ago.

There was no statistically significant difference between both groups as regards pretreatment fibrosis stage by fibro scan with $\mathrm{P}$ value $>0.05$ (Table 1 ).
In group A: 18 patients (12\%) were $\mathrm{F} 0-1$, 48 patients $(32 \%)$ were $\mathrm{F} 2,45$ patients (30\%) were $\mathrm{F} 3$ and 39 patients (26\%) were $\mathrm{F} 4$, mean pretreatment fibro scan 10.2 (Kpa).

In group B: 16 patients (11\%) were F0-1, 50 patients $(33 \%)$ were $\mathrm{F} 2,42$ patients (28\%) were $\mathrm{F} 3$ and 42 patients (28\%) were $\mathrm{F} 4$, mean pre-treatment fibro scan was $10.5(\mathrm{Kpa})$.

Table(1): Comparison between the studied groups as regards fibrosis stage (pretreatment fibroscan)

\begin{tabular}{|c|c|c|c|}
\hline $\begin{array}{ll}\text { Fibrosis stages } & \text { Groups } \\
\end{array}$ & Group A & Group B & $P$ value \\
\hline F0-F1 & $18(12 \%)$ & $16(11 \%)$ & \multirow{6}{*}{$>0.05$} \\
\hline F2 & $48(32 \%)$ & $50(33 \%)$ & \\
\hline F3 & $45(30 \%)$ & $42(28 \%)$ & \\
\hline F4 & $39(26 \%)$ & $42(28 \%)$ & \\
\hline Total & $150(100 \%)$ & $150(100 \%)$ & \\
\hline FibroScan score (kPa) & $\begin{array}{c}10.2(7.25- \\
19.60)\end{array}$ & $\begin{array}{c}10.5(7.43- \\
19.75)\end{array}$ & \\
\hline
\end{tabular}

Data were expressed as and number (\%) and median (interquartile range 1-3).

There was no statistically significant difference between both studied groups as regards fibrosis stage effect on SVR12 (Table 2).

In group A, SVR12 was achieved in $98 \%$ of patients with lower fibrosis stages (F0, F1, F2) but only achieved in $93 \%$ of patients with higher fibrosis stages (F3, F4).

In group B, SVR12 was achieved in $91 \%$ of patients with lower fibrosis stages (F0, F1, F2) but only achieved in $88 \%$ of patients with higher fibrosis stages $(\mathrm{F} 3$, F4).

Table (2): Comparison between the studied groups as regards the effect of fibrosis stage on SVR12

\begin{tabular}{|c|c|c|c|c|c|}
\hline \multirow{2}{*}{ Groups } & \multicolumn{2}{|c|}{ Group A } & \multicolumn{2}{c|}{ Group B } & P value \\
\cline { 2 - 5 } $\begin{array}{l}\text { Fibrosis } \\
\text { stages }\end{array}$ & Response & $\begin{array}{c}\text { Non } \\
\text { Response }\end{array}$ & Response & $\begin{array}{c}\text { Non } \\
\text { Response }\end{array}$ & \\
\cline { 1 - 5 } F0, F1, F2 & $65 / 66(98 \%)$ & $1 / 66(2 \%)$ & $60 / 66(91 \%)$ & $6 / 66(9 \%)$ & $>\mathbf{0 . 0 5}$ \\
\hline
\end{tabular}




\begin{tabular}{|c|c|c|c|c|c|}
\hline F3 , F4 & $78 / 84(93 \%)$ & $6 / 84(7 \%)$ & $72 / 84(86 \%)$ & $\begin{array}{c}12 / 84(14 \\
\%)\end{array}$ & $>\mathbf{0 . 0 5}$ \\
\hline
\end{tabular}

Data were expressed as number/total number (\%).

There was no statistically significant difference as regards the effect of fibrosis stage on SVR12 and SVR24 in group A and group B patients (Figure 1).

In group A, SVR12 and SVR24 was
In group B, SVR12 and SVR24 was achieved in $91 \%$ of patients with lower fibrosis stages (F0, F1, F2) and patients with fibrosis stage F3, F4 SVR12 was achieved in $86 \%$ of patients while SVR24

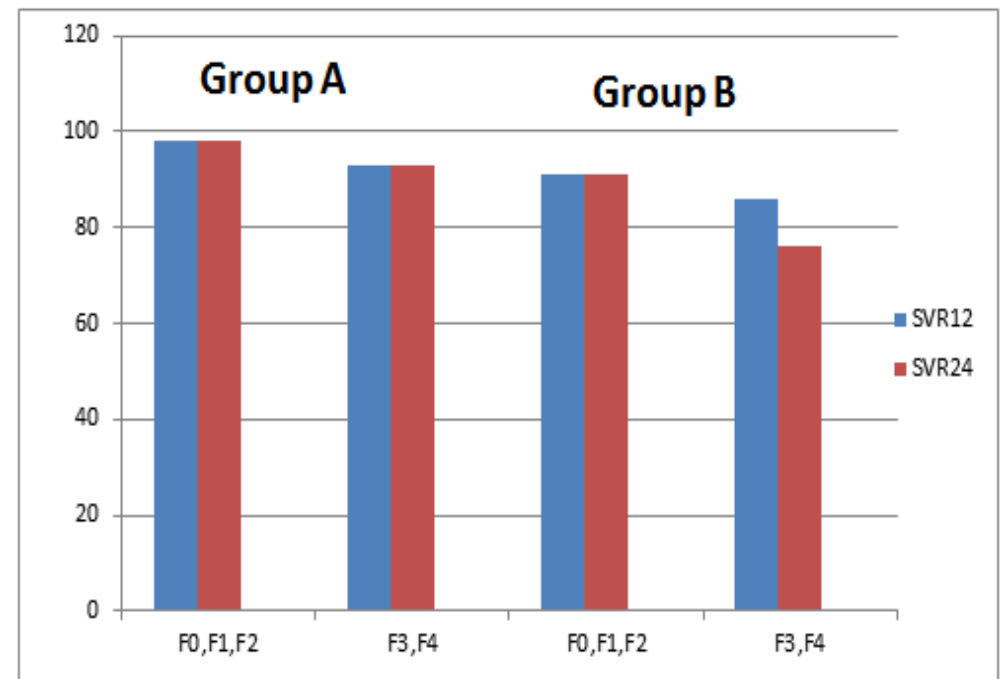

achieved in $98 \%$ of patients with lower fibrosis stages (F0, F1, and F2) and in 93\% of patients with higher fibrosis stages was achieved in $76 \%$ of patients while SVR24. (F3, F4).

Data were expressed as (\%).

Figure (1): Comparison between the effect fibrosis stage on SVR12 and SVR24 in both groups

There was statistically significant difference as regards pre-treatment and post-treatment fibroscan score in both

both groups, in group A pretreatment fibroscan score was 10.2(7.25-19.60) Kpa. and post treatment fibroscan score

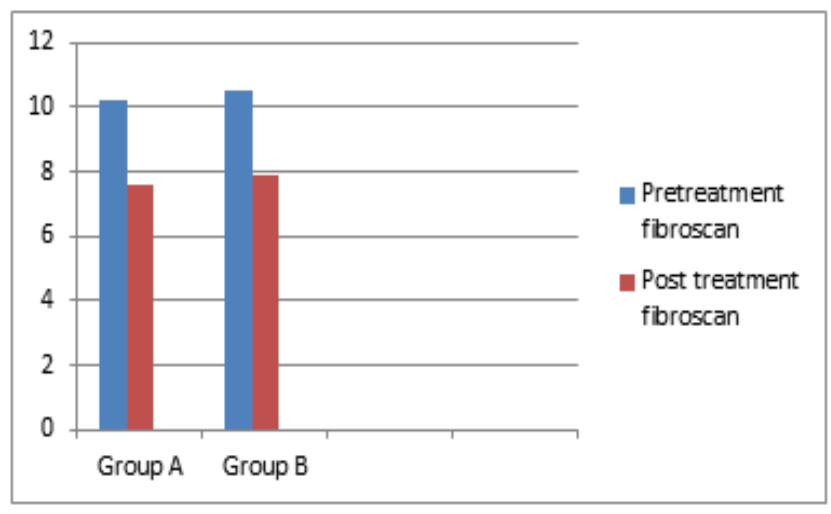

groups, $\mathrm{P}$ value $\leq 0.05$ (Figure 2).

Post treatment fibroscan score was lower than pretreatment fibroscan score in was 7.6(5.46-12.40) Kpa and in group B pretreatment fibroscan score was 


\section{BENEFIT OF ADDING SOFOSBUVIR TO INTERFERON AND RIBAVIRIN...}

10.5(7.43-19.75) Kpa, and post treatment fibroscan score was 7.9(5.5-13.6) Kpa.

Data are expressed as median (interquartile range 1-3)(Kpa)

Figure (2): Comparison between pretreatment and post-treatment fibroscan score in both groups

PCR was negative in $237(79 \%)$ patients 4 weeks after the start of treatment, in $300(100 \%)$ of patients at the

end of treatment, SVR12 in 275(92\%) patients, SVR24 and SVR48 in 267(89\%) patients (Table 3).

Table (3): Virological response in all patients

\begin{tabular}{|c|c|c|}
\hline $\mathrm{Tr}_{\text {Treatment }}$ Response & Negative viremia & Positive viremia \\
\hline RVR & $237 / 300(79 \%)$ & $63(21 \%)$ \\
\hline ETR & $300 / 300(100 \%)$ & $0 / 300(0 \%)$ \\
\hline SVR 12 & $275 / 300(92 \%)$ & $25 / 300(8 \%)$ \\
\hline SVR 24 & $267 / 300(89 \%)$ & $33 / 300(11 \%)$ \\
\hline SVR 48 & $267 / 300(89 \%)$ & $33 / 300(11 \%)$ \\
\hline
\end{tabular}

Data were expressed as number/total number (\%).

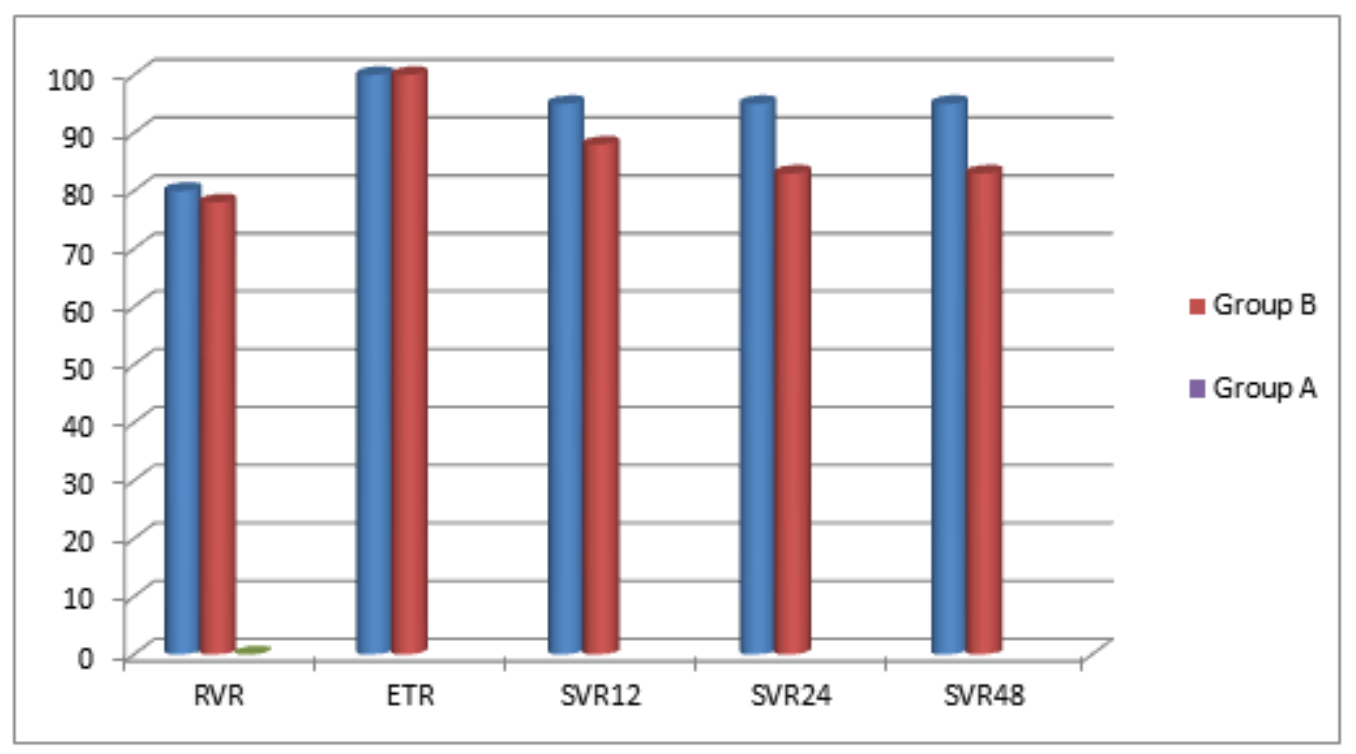

There was no statistically significant difference between both studied groups as regards RVR and ETR. There is statistically significant difference between Data were expressed as $(\%)$.

Figure (3): Comparison between the studied groups as regards virological response.

There was no statistically significant difference between both groups as regards side effects (table 4). both studied groups as regards SVR12, SVR24 and SVR48 where group A showed better virological response than group B (Figure 3). 
Table (4): Comparison between the studied groups as regards side effects of treatment

\begin{tabular}{|l|l|l|l|}
\hline Variables & $\begin{array}{l}\text { GroupA } \\
\text { N=150 }\end{array}$ & GroupB N=150 & \multirow{2}{*}{ P-value } \\
\hline Anemia & $45(30 \%)$ & $40(27 \%)$ & \\
\hline Thrombocytopenia & $6(4 \%)$ & $6(4 \%)$ & \\
\hline Neutropenia & $18(12 \%)$ & $15(10 \%)$ & \\
\hline Alopecia & $3(2 \%)$ & $2(1 \%)$ & \multirow{3}{*}{$>0.05$ (NS) } \\
\hline Fatigue & $8(5 \%)$ & $10(7 \%)$ & \\
\cline { 1 - 3 } Headache & $7(5 \%)$ & $12(8 \%)$ & \\
\hline Loss of weight & $3(2 \%)$ & $3(2 \%)$ & \\
\cline { 1 - 3 } Myalgia & $12(8 \%)$ & $13(9 \%)$ & \\
\hline Pruritis & $11(7 \%)$ & $9(6 \%)$ & \\
\cline { 1 - 3 } Depression & $3(2 \%)$ & $1(1 \%)$ & \\
\hline
\end{tabular}

Data are expressed as number/total number (\%).

\section{DISCUSSION}

In our study, both treatment groups were comparable in their demographic data. The age, sex abd BMI in different studied groups showed no statistically significant difference between both groups. Our findings were consistent with Jin et al. (2013) who found that there was no statistically significant difference as age and BMI were similar between two groups. These results agreed with $E l$ Raziky et al. (2013) who found that there was no statistically significant difference between both treatment groups regarding demographic features of the studied patients for age and BMI.

Izumi et al. (2014) they found that there was a statistically significant difference as the mean of age was higher in the alfa-2a group than in the alfa- $2 b$ group. The difference between two studies may be due to our small sample size and racial differences.
In our study, we found that there was no statistically significant difference between two groups as regards laboratory data. These results were in harmony with Jin et al. (2013) who found that there was no statistically significant difference between two groups as regards serum ALT levels. Also, these results agreed with El Raziky et al. (2013) who found that there was no statistically significant difference between both treatment groups as regards the laboratory data except for AFP as serum AFP was significantly higher in the group treated with peginterferon alpha-2a.

Regarding fibrosis stage and fibrosis 4 score (pretreatment assessment), in our study, we found that there was no significant difference as both groups were matching together as regards fibrosis stage. These results agreed with El Raziky et al. (2013) and Elwakeel et al. (2013) who found that there was no significant 


\section{BENEFIT OF ADDING SOFOSBUVIR TO INTERFERON AND RIBAVIRIN... 419}

difference between two groups regarding fibrosis stage.

Regarding pre-treatment and posttreatment fibroscan score in both groups in our study, there were statistical significant differences between both groups as regard pre-treatment and posttreatment fibroscan. This was consistent with Martinez et al. (2011) who showed a significant decrease in mean liver stiffness, and Arima et al. (2010) showed a median decrease (pre-treatment to SVR48). They followed patients for an additional two years after the end of treatment and found that the median LS score was stable.

In our study, we found that there was no statistically significant difference between two groups as regards the effect of fibrosis stage on SVR12 and SVR24. These results conflicted with Taha et al. (2010) who found that the degree of liver fibrosis was statistically significant associated with sustain virological response (SVR) and relapse rate.

As regards PCR after 4 weeks, in our study, we found that there was no statistically significant difference between two groups as regards virological response. These results were in harmony with Chekuri et al. (2016) who found that there was no statistically significant difference between two groups as RVR did not differ significantly between both groups. Also, these results agree with Coppola et al., (2012) found that there was no statistically significant difference.

As regards PCR after end of treatment between two studied groups, in our study, we found that there was no statistically significant difference between two groups at the end of treatment response (ETR).
Chekuri et al. (2016) found that there was no statistically significant difference between two groups as regards ETR.

As regards PCR after 24 and 48 weeks after end of treatment (SVR24 and SVR48) between two studied groups, in our study, we found there was a statistically significant difference between both studied groups as regards SVR24 and SVR48 where group A showed better virological response than group $\mathrm{B}$. These results were in harmony with Chekuri et al. (2016).

As regards side effects between two studied groups, in our study, we found that there was no statistically significant difference between both groups as the most common adverse events included influenza-like symptoms, and the hematologic events of anemia, neutropenia and thrombocytopenia. Our findings were consistent with Goyal et al. (2009) who found that there was no statistically significant difference between both groups as the types and frequencies of adverse events were similar among the two groups. Also Rumi et al. (2010) found that there was no statistically significant difference between both groups. Elwakeel et al. (2013) found that there was no statistically significant difference between both naïve and experienced groups as the frequency of severe adverse events were not different between both.

\section{CONCLUSION}

Adding Sofosbuvir to Interferon and Ribavirin in retreating chronic hepatitis $\mathrm{C}$ patients non responders to Interferon and ribavirin improved the response of treatment with SVR 95\% in naïve patients and $83 \%$ in experienced patients, and causes regression of liver fibrosis. 


\section{MOHAMED BADRY BASTAWY et al.,}

\section{REFERENCES}

1. Arima Y, Kawabe N, Hashimoto S, Harata M, Nitta $Y$ and Murao $M$ (2010): Reduction of liver stiffness by interferon treatment in the patients with chronic hepatitis C. Hepatol Res., 40:383-92.

2. Castera L. (2012): Non-invasive methods to assess liver disease in patients with hepatitis B or C. Gastroenterology, 142:1293-302.

3. Chekuri S, Nickerson J, Bichoupan $\mathrm{K}$, Sefcik R, Doobay $K$ and Chang $S$ (2016): Liver Stiffness Decreases Rapidly in Response to Successful Hepatitis C Treatment and Then Plateaus. PLoS ONE, 11(7): e0159413.

4. Clinton Miller M (1992): Clinical epidemiology and biostatistics, published by Williams \& Wilkins, Maryland: 3rd edition.

5. Coppola N, Pisaturo M, Tonziello G, Sagnelli C, Sagnelli E and Angelillo IF (2012): Efficacy of Pegylated interferon $\alpha-2 a$ and $\alpha-2 b$ in patients with genotype 1 chronic hepatitis $\mathrm{C}$ : a meta-analysis. BMC Infect Dis., 12:357-63.

6. El Raziky M, Fathalah WF, El-Akel WA, Salama A, Esmat $G$ and Mabrouk $M$ (2013): The Effect of Peginterferon Alpha-2a vs. Peginterferon Alpha-2b in Treatment of Naive Chronic HCV Genotype-4 Patients: A Single Centre Egyptian Study. Hepat Mon., 13(5):e30780.

7. Elwakeel EA, Amachawadi RG, Nour AM, Nasser ME, Nagaraja TG and Titgemeyer EC (2013): In vitro degradation of lysine by ruminal fluid-based fermentations and by Fusobacterium necrophorum. J Dairy Sci., 96: 495-505.

8. Goyal N, Jain N, Rachapalli V, Cochlin DL and Robinson $M$ (2009): Non-invasive evaluation of liver cirrhosis using ultrasound. Clin Radiol., 64:1056-66.

9. Izumi N, Yokosuka O, Kawada N, Osaki $\mathbf{Y}$, Yamamoto $\mathrm{K}$, Sata $\mathrm{M}$, Ishikawa $\mathrm{H}$, Ueki T, Hu W, McPhee F, Hughes EA and Kumada H (2014): Daclatasivir combined with peginterferon alfa- $2 b$ and ribavirin in
Japanese patient infected with hepatitis C genotype 1. Antivir Ther., 19:501-510.

10. Jin Y J, Lee JW, Lee JI, Park SH, Park CK, Kim YS and Han S (2013): Multicenter comparison of PEG-IFN $\alpha 2 \mathrm{a}$ or $\alpha 2 \mathrm{~b}$ plus ribavirin for treatment-naïve $\mathrm{HCV}$ patient in Korean population. BMC Gastroenterol., 13:74-76.

11. Kouyoumjian SP, Chemaitelly $H$ and AbuRaddad LJ (2018): Characterizing hepatitis C virus epidemiology in Egypt: systematic reviews, meta-analyses, and metaregressions. Sci Rep., 8: 1661-66.

12. Martínez SM, Crespo G, Navasa $M$ and Forns X (2011): Noninvasive assessment of liver fibrosis. Hepatology, 53(1):325-35.

13. Omran D, Alboraie M, Zayed RA, Wifi MN, Naguib M, Eltabbakh M, Abdellah M and El Kassas M (2018): Towards hepatitis $\mathrm{C}$ virus elimination: Egyptian experience, achievements and limitations World $\mathbf{J}$ Gastroenterol., 24(38): 4330-4340.

14. Ruane PJ, Ain D, Stryker R, Meshrekey R, Soliman M, Wolfe PR, Riad J, Mikhail S, Kersey K, Jiang D, Massetto B, Doehle B, Kirby BJ, Knox SJ, McHutchison JG and Symonds WT (2015): Sofosbuvir plus ribavirin for the treatment of chronic genotype 4 hepatitis $C$ virus infection in patients of Egyptian ancestry. J Hepatol., 62: 1040-1046.

15. Rumi MG, Aghemo A, Prati GM, D'Ambrosio R, Donato MF, Soffredini R, Del Ninno E, Russo $A$ and Colombo $M$ (2010): Randomized study of peginterferonalpha2a plus ribavirin vs peginterferonalpha2b plus ribavirin in chronic hepatitis $\mathrm{C}$. Gastroenterology, 138:108-115.

16. Taha AA, El-Ray A, El-Ghannam $M$ and Mounir B (2010): Efficacy and safety of a novel pegylated interferon alpha-2a in Egyptian patients with genotype 4 chronic hepatitis C. Can J Gastroenterol., 24: 597602.

17. Waked I, Doss W, El-Sayed MH, Estes C, Razavi H, Shiha G, Yosry A and Gamal Esmat (2014): The current and future disease 
BENEFIT OF ADDING SOFOSBUVIR TO INTERFERON AND RIBAVIRIN... 421

burden of chronic hepatitis $\mathrm{C}$ virus infection

in Egypt. Arab J Gastroenterology, 15: 45-52. 
تقييم فو ائد اضافة عقار السوفوسبوفير الى الانترفيرون

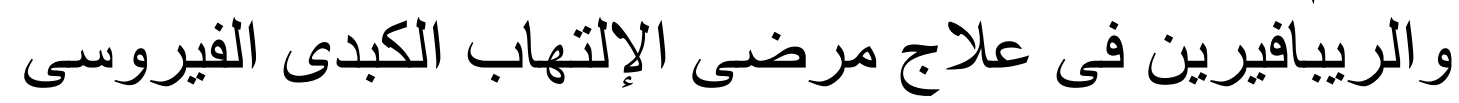

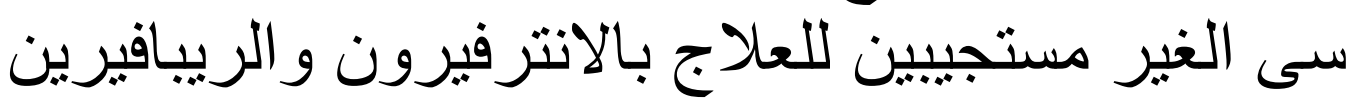
محمد بدرى بسطاوى، مدحت حسن السحار **، سيد فاروق محمد*، أحمد حنفى أحمد

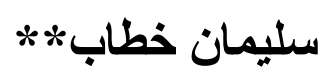

قسم الكيمياء* قسم الكبد والجهاز الهضمى، كلية الطب، جامعة الأزهر، وقسم الجهاز الهضمي و

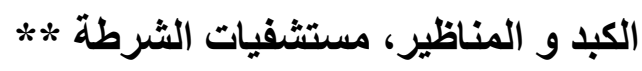

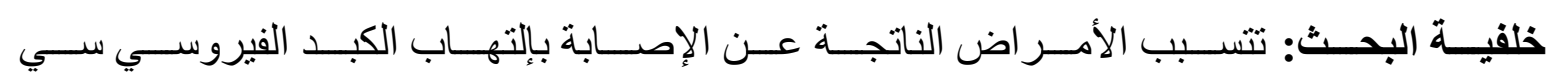

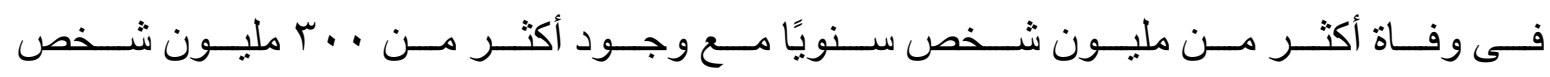

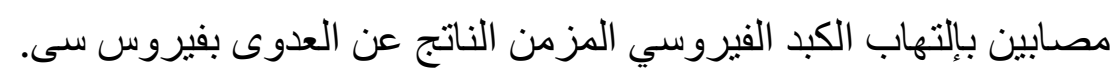

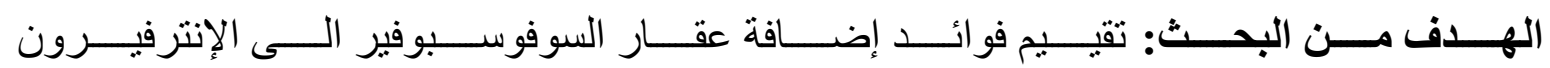

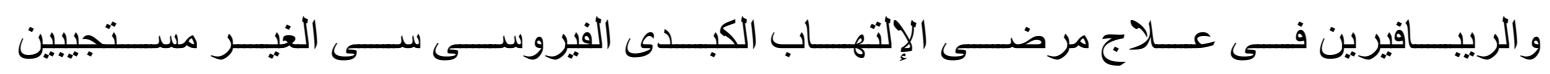

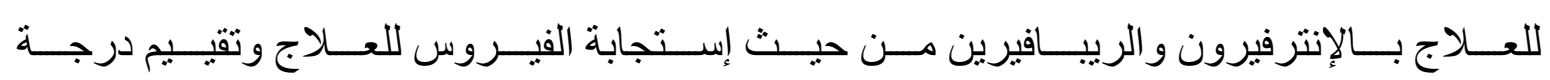
تليف الكبد قبل و بعد الإنتهاء من العلاج.

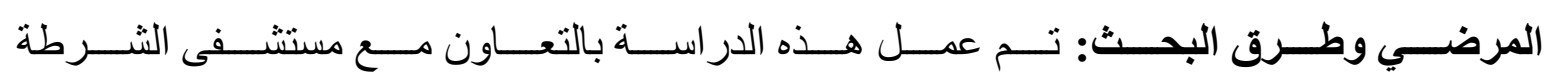

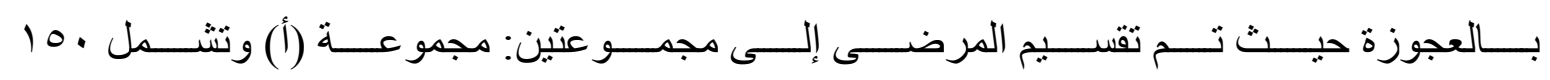

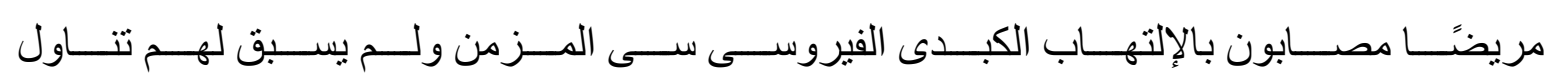

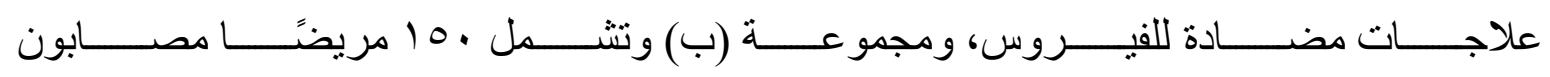

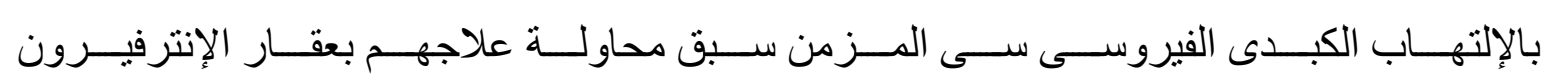

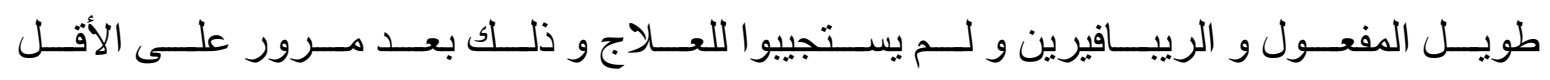
ستة اشهر من تناول العلاج السابق.

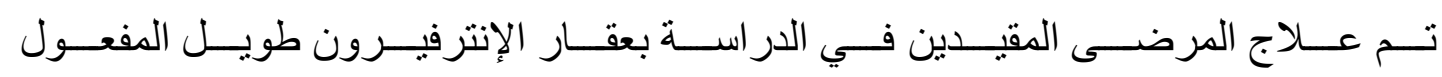

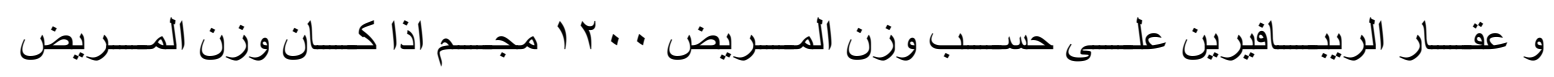

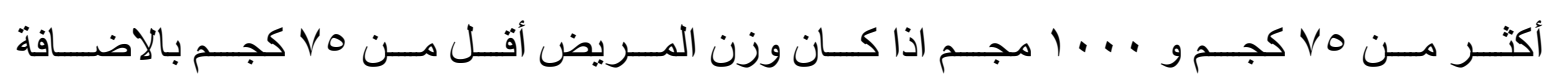

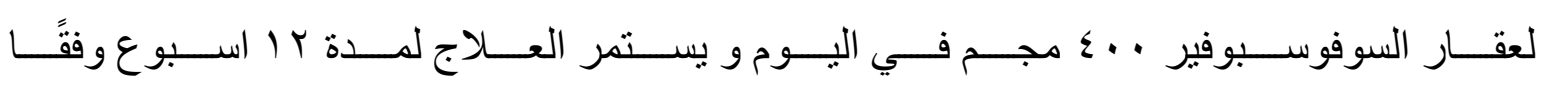




\section{BENEFIT OF ADDING SOFOSBUVIR TO INTERFERON AND RIBAVIRIN... 423}

)، حيـث تـــم تحـديث

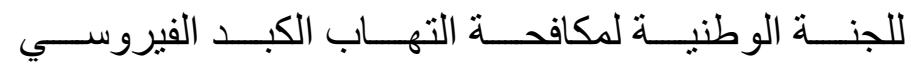

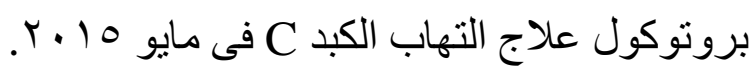

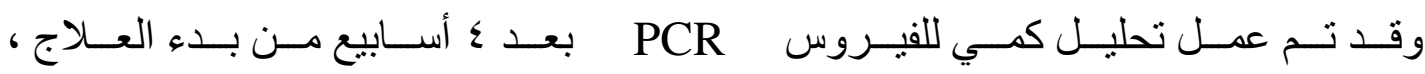

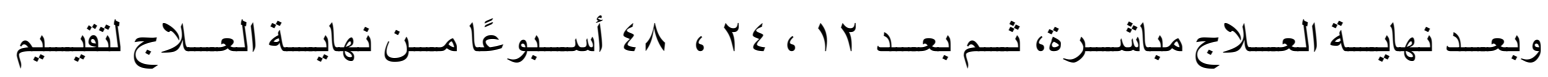
الاستجابة الفيروسية في كلا المجمو عتين.

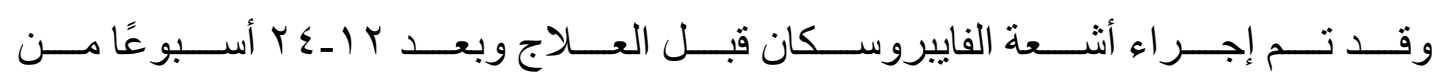
نهاية العلاج لتقييم تليف الكبد.

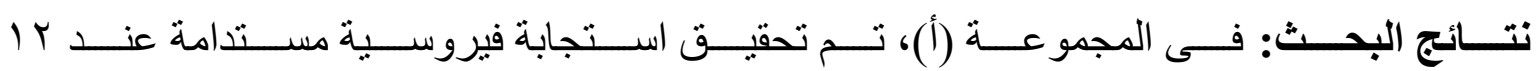

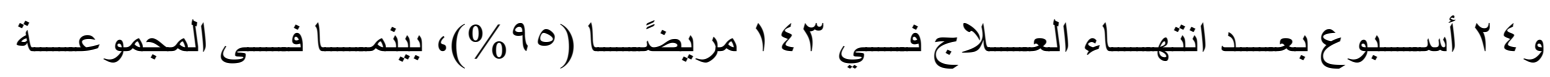

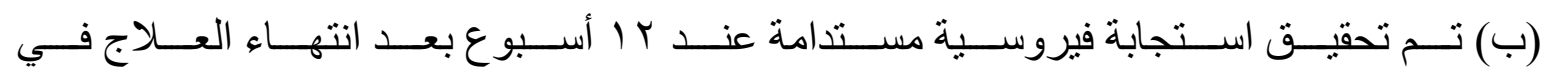

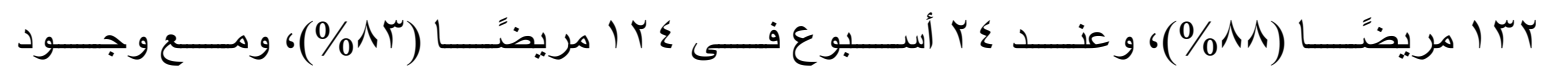

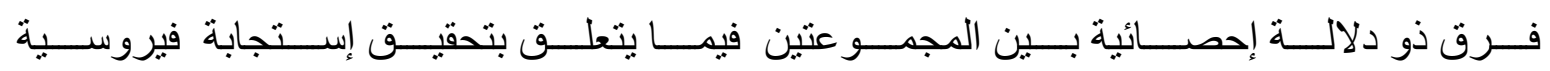

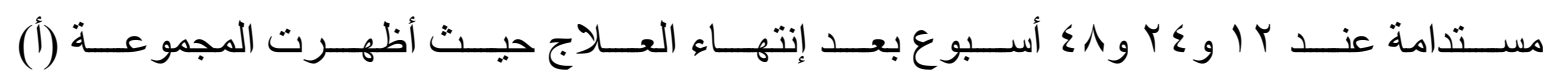
إستجابة فيروسية أفضل من المجموعة (ب).

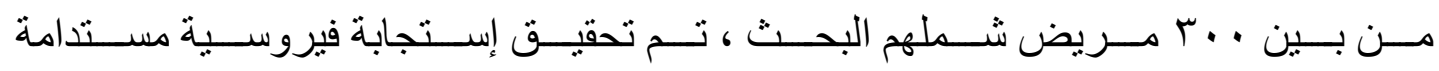

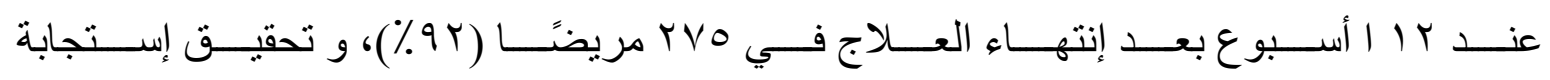

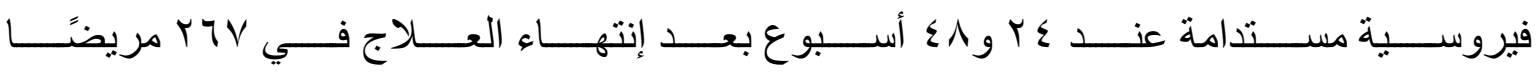
.$(\%$. $(.9)$

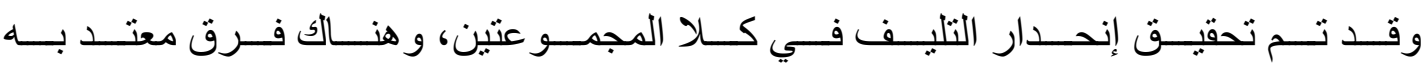
إحصائياً فيما يتعلق بأثعة الفاييروسكان قبل الهعالجة وبعدها في كلا المجمو عنين.

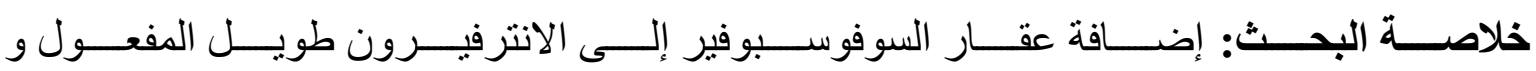

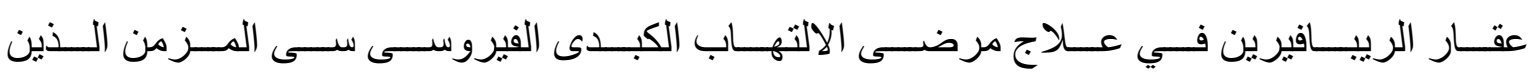

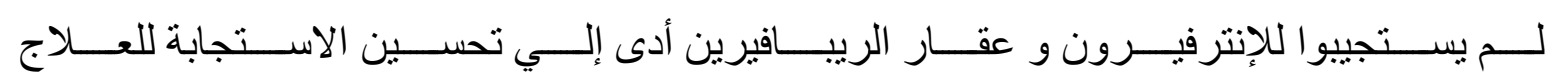
وتسبب فى حدوث نر اجع فى درجة التليف الكبدى. 